https://doi.org/10.11646/zootaxa.4329.2.6

http://zoobank.org/urn:lsid:zoobank.org:pub:EBE52F5C-4ED7-4601-B6DE-C21D6D9FBEFD

\title{
A distinctive new species of biting midge in the subgenus Euprojoannisia Brèthes from Mexico with new records of Neotropical species of Forcipomyia Meigen (Diptera: Ceratopogonidae)
}

\author{
HERON HUERTA ${ }^{1,3} \&$ GUSTAVO R. SPINELLI ${ }^{2}$ \\ ${ }^{1}$ Laboratorio de Entomología, InDRE, Francisco de P. Miranda No 177, Col. Unidad Lomas de Plateros, Del. A. Obregón, CP. 01480 , \\ Ciudad de México, México. \\ ${ }^{2} I L P L A-C O N I C E T$, UNLP-División Entomología, Museo de La Plata, Boulevard 120 S/N e/61 y 62 La Plata-Buenos Aires-Argen- \\ tina.E-mail: spinelli@fcnym.unlp.edu.ar \\ ${ }^{3}$ Corresponding author. E-mail: cerato_2000@yahoo.com
}

\begin{abstract}
A new species of biting midge, Forcipomyia (Euprojoannisia) bibaana, is described and illustrated from an adult male collected in the state Oaxaca, Mexico. The first records of Forcipomyia (E.) mortuifolii Saunders, F. (Lasiohelea) cornuta Saunders and $F$. (L.) stylifer (Lutz) are provided from Mexico as well as the first record of $F$. (L.) anitae Huerta \& IbáñezBernal from Guatemala.
\end{abstract}

Key words: Forcipomyiinae, biting flies, taxonomy, distribution

\section{Introduction}

Biting midges of the genus Forcipomyia Meigen are very diverse and include 1154 extant and 32 extinct fossil species (Borkent 2016). The genus has considerable economic impact because many species are pollinators of cocoa and rubber trees (Hevea) (Bystrak \& Wirth 1978). Species of Forcipomyia inhabit all zoogeographical regions except Antarctica, but many species still await formal description and names. This genus is currently divided into 36 subgenera (Borkent 2016). The current infrageneric classification is based mainly on adult morphology, however, nearly $12 \%$ of species are known from their immature stages (Borkent 2014).

Borkent \& Spinelli (2007) listed 211 Neotropical species of Forcipomyia in 18 subgenera, and in Mexico at least 14 subgenera and 40 species are known. However, 17 species of different subgenera were subsequently described or recorded from this region (Marino \& Spinelli 2008, Spinelli et al 2012, Marino et al 2013). Presently 17 species in the subgenus Euprojoannisia Brèthes are known from the Neotropical region (Borkent \& Spinelli 2007), of which three have been recorded from Mexico, Forcipomyia (E.) calcarata (Coquillett) from Tabasco and Quintana Roo, F. (E.) dowi Bystrak \& Wirth from Quintana Roo, and $F$. (E.) navaiae Bystrak \& Wirth from Yucatan. The subgenus Lasiohelea Kieffer includes 11 species in the Neotropics (Borkent \& Spinelli 2007), with only one species recorded from Mexico, F. (L.) anitae Huerta \& Ibáñez-Bernal from Chiapas and San Luis Potosi. Herein, we describe a new species of Forcipomyia (Euprojoannisia) from Oaxaca, Mexico, and provide new records of four previously described species from the Neotropical region.

\section{Material and methods}

Specimens were collected with Malaise traps and CDC light traps in different regions of Mexico (states of Guerrero, Oaxaca and Veracruz) and a locality of Guatemala (Livingston Island). Unless otherwise indicated, specimens were preserved in $70 \%$ ethanol and subsequently cleared, dissected and mounted on microscope slides 
by the techniques described by Borkent \& Spinelli (2007), except for a few specimens mounted in Euparal. Illustrations were prepared with the aid of a drawing tube attached to an Olympus BX50 compound microscope, and photographs were taken with a Lumenera Infinity 1 camera mounted on the Olympus BX50.

Morphological terms follow those in the chapter on Ceratopogonidae in the recent Manual of Central American Diptera (Borkent et al 2009). Special terms for Forcipomyia (Euprojoannisia) are those provided by Bystrak \& Wirth (1978). The holotype of the new species and other voucher specimens are deposited in the Collection of Arthropods of Medical Importance, Mexico City, Mexico (CAIM).

\section{Systematics}

\section{Diptera: Ceratopogonidae}

\section{Subfamily Forcipomyiinae}

\section{Genus Forcipomyia Meigen}

Forcipomyia Meigen, 1818: 73. Type species: Tipula bipunctata Linnaeus, designated by Westwood, 1840: 126. Generic name first published in synonymy with Ceratopogon but available under ICZN Code Article 11(e).

Euforcipomyia Malloch, 1915: 312. Type species: Euforcipomyia hirtipennis Malloch (=Ceratopogon palustris Meigen), by original designation.

Cryptoscena Enderlein, 1936: 51. Type species: Ceratopogon palustris Meigen, by monotypy.

Proforcipomyia Saunders, 1957: 662 (as subgenus of Forcipomyia). Type species: Forcipomyia wirthi Saunders, by original designation.

\section{Subgenus Euprojoannisia Brèthes, 1914}

Euprojoannisia Brèthes, 1914: 155. Type species: Euprojoannisia platensis Brèthes, by original designation.

Euforcipomyia Malloch, 1915: 312. Type species: Euforcipomyia hirtipennis Malloch (=Ceratopogon palustris Meigen), by original designation.

Cryptoscena Enderlein, 1936: 51. Type species: Ceratopogon palustris Meigen, by monotypy.

Proforcipomyia Saunders, 1957: 662 (as subgenus of Forcipomyia). Type species: Forcipomyia wirthi Saunders, by original designation.

\section{Forcipomyia (Euprojoannisia) bibaana, new species}

(Figs. 1-5)

Type material. Male. Holotype. MEXICO, Oaxaca, Municipio San Juan Guichicovi, Localidad El Zacatal, Malaise trap, 26-28-July-2009, Salceda, S.B., Rodríguez, A.A. \& Ordóñez, A.J., Coll., 1 male (CAIM).

Diagnosis. Male: Only species of Neotropical Forcipomyia (Euprojoannisia) with posterior margin of sternite 9 with two distinctive lateral, triangular lobes and a posteromesal, rounded setose lobe; gonocoxite L-shaped with stout anteromesal projection bearing pair of short, very stout spines, aedeagus short, stout. Female unknown.

Description. Head. Brown. Eyes abutting medially for length of four ommatidia, without interommatidial spicules. Antenna (Fig. 1) with well developed plume, extending to base of flagellomere 13, flagellomeres 2-9 spherical, 5-9 fused, $101.6 \times$ longer than 11, 10-13 elongate; flagellomere 13 with apical nipple, not constricted basally; antennal ratio 0.37 . Palpus with third segment elongated, with rounded deep sensory pit; segments 4,5 partly fused; palpal ratio 3.0 .

Thorax. Pale yellowish; scutellum with 8 setae. Legs light brown; prothoracic tarsal ratio 2.2; mesothoracic tarsal ratio 1.7; metathoracic tarsal ratio 1.6. Wing (Fig. 2) pale, without pattern; base of $\mathrm{M}_{2}$ not visible; 1st radial cell obliterated, 2nd radial cell well developed; cubital fork distal to level of apex of costa; apices of $\mathrm{CuA}_{1}, \mathrm{CuA}_{2}$ obsolete; wing length $1.07 \mathrm{~mm}$, breadth $0.35 \mathrm{~mm}$; costal ratio 0.48 . Halter whitish. 

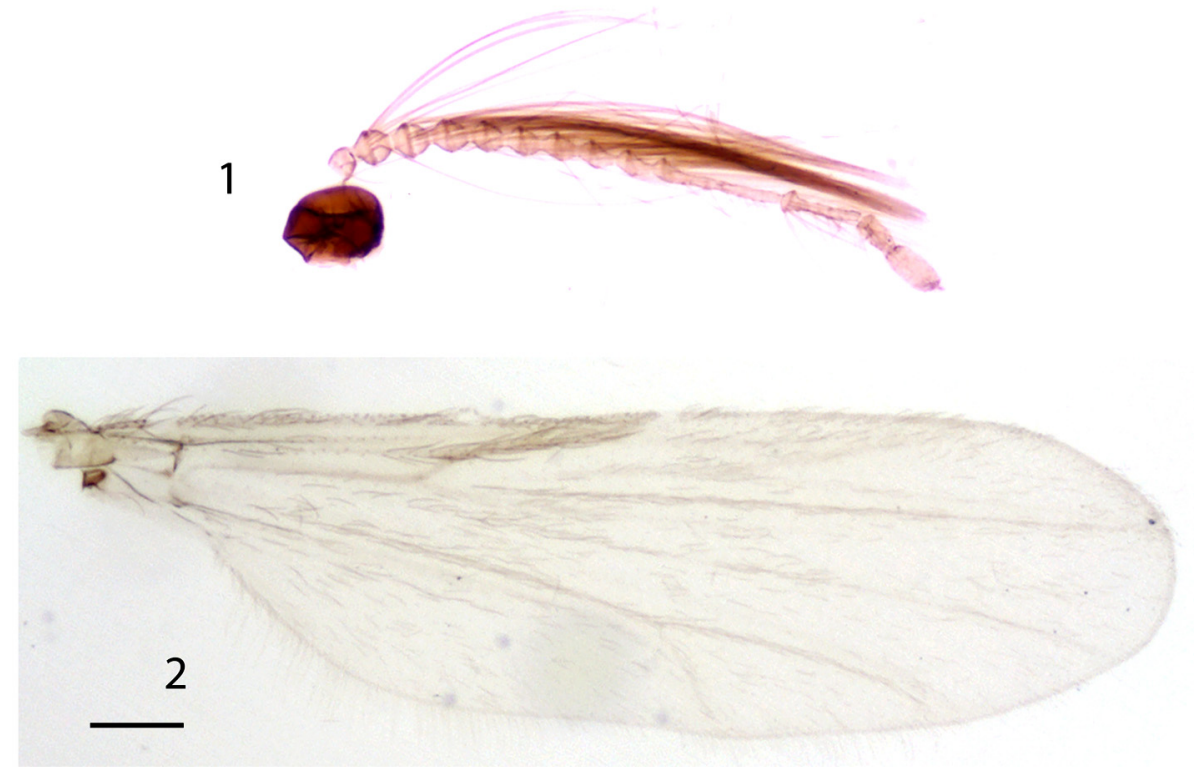

FIGURES 1-2. Forcipomyia (Euprojoannisia) bibaana n. sp. Male. 1. Antenna, lateral view. 2. Wing. Scale: $0.1 \mathrm{~mm}$.

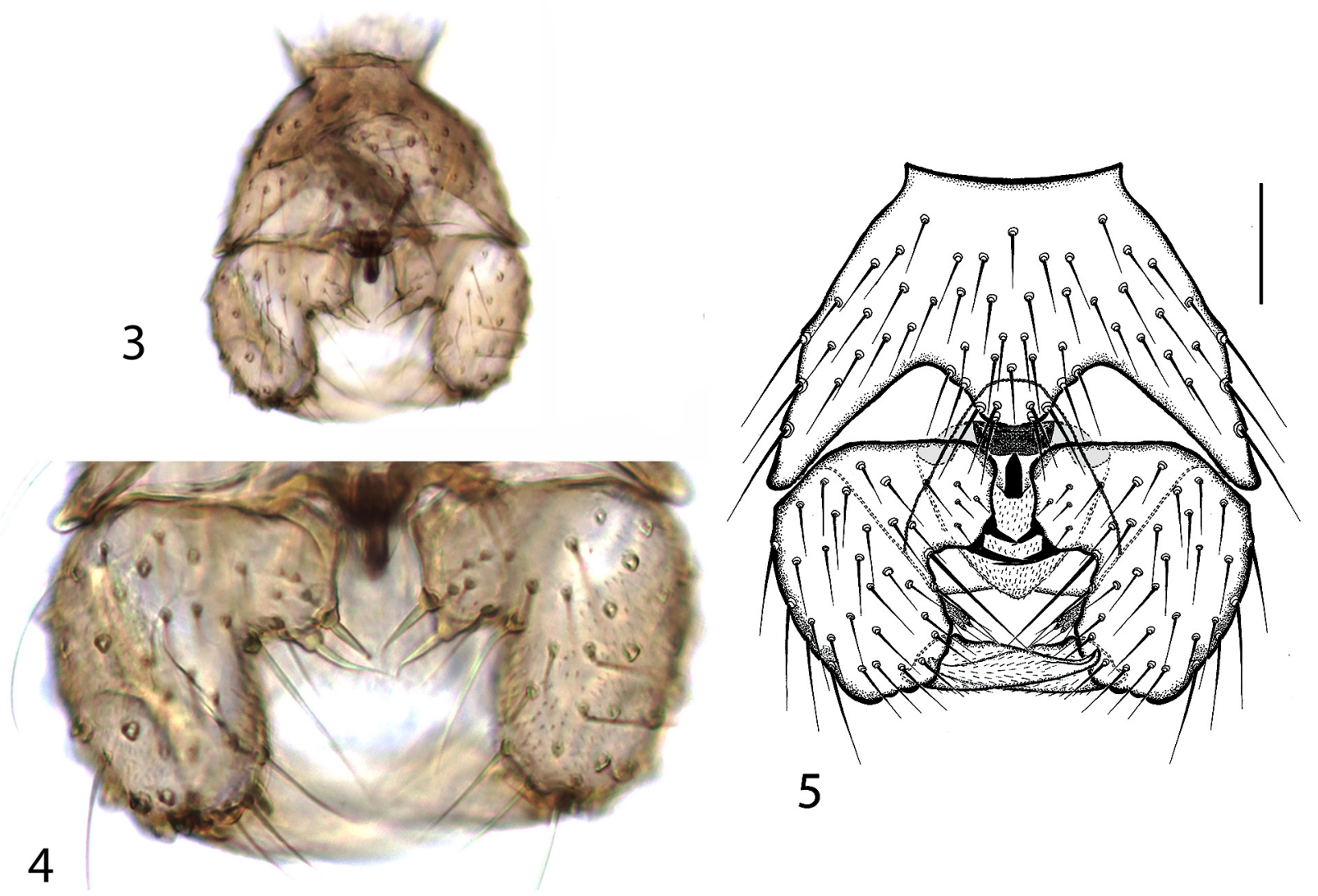

FIGURES 3-5. Forcipomyia (Euprojoannisia) bibaana n. sp. Male genitalia. 3-5. Ventral view. 4. Detail of the spines of gonocoxite. Scale: $0.1 \mathrm{~mm}$.

Abdomen. Pale brown. Genitalia (Figs. 3-5) brown. Tergite 9 short, extending to 1/4 length of gonocoxite; posterior margin truncate, with elongate convergent apicolateral process bearing few apical setae; cercus lobe-like. Sternite 9 moderately narrow anteriorly, becoming increasing broader posteriorly; posterior margin with two deep 
apicolateral excavations that produce two distinctive elongate apicolateral triangular lobes and a rounded posteromesal setose lobe. Gonocoxite L-shaped, 1.1x longer than greatest breadth, with stout anteromesal projection bearing pair of short, very stout spines; gonostylus 0.9 length of gonocoxite, slightly curved apically, tapering to pointed tip. Parameres absent; gonocoxal apodemes slender, V-shaped. Aedeagus very short, stout; basal arms broad, heavily sclerotized, apices recurved; basal arch very shallow, extending $1 / 20$ of total aedeagal length; portion distal with short process hook-shaped, bent ventrocephalad.

Female. Unknown.

Derivation of specific epithet. The specific epithet is from the Zapotec language, bibaana=strange, in reference to the unusual shape of the male gonocoxite.

Distribution. This species is known only from the type locality, El Zacatal, in the state of Oaxaca, Mexico.

Taxonomic discussion. The peculiar L-shaped gonocoxite and the trilobed posterior margin of the sternite 9 clearly distinguish F. bibaana from all other Neotropical and Nearctic species of the subgenus in which the male sex is known. The anteromesal projection of gonocoxite bearing pair of short, very stout spines, is distinctive character of this new species.

\section{New records of other species}

\section{Forcipomyia (Euprojoannisia) mortuifolii Saunders}

Forcipomyia (Proforcipomyia) mortuifolii Saunders 1959: 35. Trinidad. (all stages; figs. female habitus, palpus, tibial comb, spermathecae, wing, antenna, male genitalia, pupa, larva); Chan \& LeRoux 1971: 1329 (phylogenetic relationships).

Forcipomyia (Euforcipomyia) mortuifolii: Wirth 1974: 14 (in New World catalogue south of the USA).

Forcipomyia (Euprojoannisia) mortuifolii: Bystrak \& Wirth 1978: 29 (all stages; distribution; figs. anterior veins of wings, palpus, frontal sclerite, flagellum, tibial comb of fore, mid and hind legs, male genitalia, detail of male sternite 9 , spermathecae, female genitalia); Wilkening et al 1985: 515 (Florida records); Borkent \& Wirth 1997: 31 (in World catalogue); Borkent \& Spinelli 2000: 14 (in New World catalogue south of the USA); Borkent \& Spinelli $2007: 49$ (in Neotropical catalogue); Borkent \& Grogan 2009: 7 (in Nearctic catalog); Grogan et al 2010: 10 (Florida record); Borkent 2016: 33 (in online World catalogue).

Material examined. MEXICO, Oaxaca, Municipio Santo Domingo Petapa, Localidad Río del Sol, Malaise trap, 29-30-June-2009, Salceda, S.B., Rodríguez, A.A. \& Ordóñez, A.J., Coll., 1 male (slide). New Mexico record.

Diagnosis. Very small species, wing length $0.95 \mathrm{~mm}$, male with ninth sternum with two mesal stout spines; gonostyle with mesal process. Female with palpus short and stout; mandible with fine teeth; oval basal flagellomeres; spermathecae slightly unequal, darkly sclerotized.

Distribution. Forcipomyia (E.) mortuifolii is widely distributed in the Caribbean region from extreme southern Florida, USA, Jamaica, Puerto Rico, Dominica, Santa Lucia and Trinidad. We provide the first record for Mexico.

\section{Subgenus Lasiohelea Kieffer, 1921}

Centrorhynchus Lutz, 1913: 62 (preoccupied by Centrorhynchus Steven or Fisher Waldheim, 1829). Type species: Centrorhynchus stylifer Lutz, by original designation.

Lasiohelea Kieffer, 1921: 115. Type species: Atrichopogon pilosipennis Kieffer (= Ceratopogon velox Winnertz), by original designation.

Parapterobosca Harant et al., 1951: 468. Type species: Parapterobosca anthropophila Harant, Huttel \& Huttel, by original designation.

Dacnoforcipomyia Chan \& Saunders, 1965: 527 (as subgenus of Forcipomyia). Type species: Forcipomyia anabaenae Chan \& Saunders, by original designation.

\section{Forcipomyia (Lasiohelea) anitae Huerta \& Ibáñez-Bernal}

Forcipomyia (Lasiohelea) anitae Huerta \& Ibáñez-Bernal, 1996: 350. Mexico. (male; figures of flagellomeres 10-13, palpus, 
cibarial spines, male genitalia, Mexico); Ronderos \& Spinelli 1999: 154 (Costa Rica and Brazil records); Borkent \& Spinelli 2000: 16 (in New World catalogue south of the USA); Marino \& Spinelli 2005: 165 (female; figures flagellum, palpus, cibarial spines, scutellum, wing, genital sclerotization, spermatheca; Argentina record); Borkent \& Spinelli 2007: 52 (in Neotropical catalogue); Borkent 2016: 43 (in online World catalog).

Lasiohelea stylifer: Macfie 1953: 7 (male; figure genitalia; Costa Rica).

Lasiohelea anitae: Huerta \& Ibáñez-Bernal 1999: 497 (female; figures flagellomeres, palpus, head, mandible, cibarial armature, anterior veins of wings, spermatheca; abdomen, distal segments; distribution).

Forcipomyia (Lasiohelea) sp.: Spinelli et al 2002: 527 (biting frogs; Argentina).

Material examined. MEXICO, Guerrero, Ayutla de los Libres, Locality La Unión, Malaise trap, 7-April-16-May2009, Marín, B.W., Coll., 1 male (slide). Oaxaca, Municipio San Juan Guichicovi, Locality El Zarzal, Malaise trap, 24-25-July-2009, Salceda, S.B., Rodríguez, A.A. \& Ordoñez, A.J., Coll., 1 male (slide). Veracruz, Municipio Actopan, Locality Soyacuautla, Malaise trap, 5-February-2009, Brigada entomológica, JSV., Coll., 3 males, 2 females (slides). GUATEMALA, Izabal, Isla Livingston, Locality Creek Chino, 12-16-July-1999, Malaise trap, Huerta, H., Coll., 1 male (slide). New Guatemala record.

Diagnosis. Male: Aedeagus divided in two sclerites, joined basally, straight inner side to subapical apex, external side expanded at the base, tapering to apex, portion distal abruptly bend to a sharp, ventrally direct point. Female: cibarial armature with 15 a 16 teeth in single row; mandible with 30-32 teeth, scutellum with 8 setae in a row.

Distribution. Forcipomyia (L.) anitae is widely distributed in the Neotropical region from Mexico, Costa Rica, Brazil (Bahia, Itabuna), to northeastern Argentina. We provide additional new Mexican records from the states of Oaxaca and Guerrero, and the first record from Guatemala.

\section{Forcipomyia (Lasiohelea) cornuta Saunders}

Forcipomyia (Lasiohelea) cornuta Saunders, 1964: 464. Costa Rica, Trinidad, Brazil. (all stages; figures larva, larval head, posterior aspect of larval body, prothoracic pseudopod, pupa, pupal respiratory organ, antenna, palpus, spermatheca, wing, male genitalia); Wirth 1974: 7 (in New World catalogue south of the USA); Aitken et al 1975: 108 (Trinidad records); Borkent \& Wirth 1997: 39 (in World catalogue); Borkent \& Spinelli 2000: 16 (in New World catalogue south of the USA); Borkent \& Spinelli 2007: 52 (in Neotropical catalogue; Borkent 2016: 44 (in online World catalogue).

Material examined. MEXICO, Veracruz, Municipio Emiliano Carranza, Locality Vega de Alatorre, CDC light trap, 15-May-2010, Brigada Entomológica, Coll., 1 male (slide). New Mexico record.

Diagnosis. Male: gonocoxite basally bearing small, sinuous, foliaceous process; aedeagus with four anterolateral process strong, horns-shaped. Female with third palpal segment short and swollen; spermatheca subspherical; other characteristic undiagnosable.

Distribution. Forcipomyia (L.) cornuta is distributed in Costa Rica, Trinidad and Brazil (São Paulo). We provide the first record from Mexico.

\section{Forcipomyia (Lasiohelea) stylifer (Lutz)}

Centrorhynchus stylifer Lutz, 1913: 63. Brazil. (female; figs. wing, palpus; habits).

Lasiohelea stylifer: Edwards 1922: 166 (combination; notes; Brazil); Macfie 1939: 171 (Brazil records); Macfie 1940: 181 (Guyana record); Macfie 1944: 298 (Trinidad, ex cacao); Lane 1945: 362 (female redescription; lectotype designation; figure antenna); Lane 1947: 161 (larva, pupa; figure larva; Brazil); Ortiz 1952: 241 (female redescription; figures wing, head, palpus, spermatheca; Venezuela); Wirth 1956: 246 (female redescription; Costa Rica); Cavalieri 1962: 363 (synopsis of Neotropical species).

Forcipomyia (Lasiohelea) stylifera: Wirth 1974: 7 (in New World catalogue south of the USA); Aitken et al 1975: 108 (Trinidad records; figure female wing); Huerta \& Ibáñez-Bernal 1996: 353 (in key to American species); Ronderos \& Spinelli 1999: 154 (redescription; figures female head, palpus, cibarial spines, scutellum, hind tibial comb, tarsal claws, wing, genital sclerotization, spermatheca, male genitalia; distribution).

Forcipomyia (Lasiohelea) stylifer: Borkent \& Wirth 1997: 43 (in World catalogue); Borkent \& Spinelli 2000: 17 (in New World catalogue south of the USA); Felippe-Bauer \& Oliveira 2001: 1116 (in list of type specimens of the Instituto Oswaldo Cruz); Spinelli et al 2005: 138 (in key Argentinean bloodsucking species); Borkent \& Spinelli 2007: 52 (in Neotropical catalogue); Borkent 2016: 46 (in online World catalogue). 
Material examined. MEXICO, Oaxaca, Municipio San Juan Guichicovi, Locality El Zacatal, potrero, CDC light trap, 27-28-July-2009, Salceda, S.B., Rodríguez, A.A. \&Ordóñez, A.J., Coll., 1 male (slide). New Mexico record.

Diagnosis. Male. Aedeagus divided in two sclerites, lightly joined basally, 2/3 of total length, distal portion slender, externally directed. Female with third palpal segment fusiform, with a distinct extension beyond the pit, fifth segment as long as fourth; 9-10 cibarial spines in one row; scutellum with 7 strong setae in a row, large circular aperture of spermathecal.

Distribution. This very common species is widely distributed in the Neotropical region from Mexico to Ecuador, Trinidad, Venezuela and northeastern Argentina. We provide the first record from Mexico.

\section{Acknowledgements}

We are grateful to Dr. Sergio Ibáñez-Bernal of INECOL for the loan of specimen of Forcipomyia (Lasiohelea). We also thank Dr. William L. Grogan, Jr. and Dr. Ryszard Szadziewski for his helpful review of an earlier draft of the manuscript.

\section{References}

Aitken, T.H.G., Wirth, W.W., Williams, R.W., Davies, J.B. \& Tikasingh, E.S. (1975) A Review of the bloodsucking midges of Trinidad and Tobago, West Indies (Diptera: Ceratopogonidae). Journal of Entomology (B), 44, 101-144.

Borkent, A. (2014) The pupae of biting midges of the World (Diptera: Ceratopogonidae), with a generic key and analysis of the phylogenetic relationships between genera. Zootaxa, 3879 (1), 001-327. https://doi.org/10.11646/zootaxa.3879.1.1

Borkent, A. (2016) World species of biting midges (Diptera: Ceratopogonidae). Available from: http://www.inhs.uiuc.edu/ research/FLYTREE/CeratopogonidaeCatalog.pdf (accessed 3 March 2017)

Borkent, A. \& Grogan, W.L. Jr. (2009) Catalog of the New World biting midges north of Mexico (Ceratopogonidae: Diptera). Zootaxa, 2273, 1-48.

Borkent, A. \& Spinelli, G.R. (2000) Catalog of the New World biting midges south of the United States of America (Diptera: Ceratopogonidae). Contributions on Entomology, International, 4, 1-107.

Borkent, A. \& Spinelli, G.R. (2007) Neotropical Ceratopogonidae (Diptera: Insecta). In: Adis, J., Arias, J.R., Rueda-Delgado, G. \& Wantzen, K.M. (Eds.), Aquatic Biodiversity in Latin America (ABLA). Vol. 4. Pensoft, Sofia-Moscow, pp. 198.

Borkent, A., Spinelli, G.R. \& Grogan, W.L. Jr. (2009) Chapter 29. Ceratopogonidae (biting midges, purrujas). In: Brown, B., Borkent, A., Cumming, J.M., Wood, D.M., Woodley, N.E. \& Zumbado, M.A. (Eds.), Manual of Central American Diptera. Vol. 1. NRC Research Press, Ottawa, Ontario, pp. 407-435.

Borkent, A. \& Wirth, W.W. (1997) World species of biting midges (Diptera: Ceratopogonidae). Bulletin of the American Museum of Natural History, 233, 1-257.

Brèthes, J. (1914) Descripción de seis Cécidomyidae (Dipt.) de Buenos Aires. Anales del Museo Nacional de Buenos Aires, 26, $151-156$.

Bystrak, P.G. \& Wirth, W.W. (1978) The North American species of Forcipomyia, subgenus Euprojoannisia (Diptera: Ceratopogonidae). United States Department of Agriculture Technical Bulletin, 1591, 51 pp.

Cavalieri, F. (1962) Notas sobre Ceratopogonidae (Dipt. Nematocera) III. Sobre un nuevo díptero hematófago para Argentina, Lasiohelea saltensis n. sp. y notas sobre las especies neotropicales de Lasiohelea. Acta Zoologica Lilloana, 18, 359-365.

Chan, K.L. \& LeRoux, E.J. (1971) Phylogenetic relationships in the Forcipomyiinae (Diptera: Ceratopogonidae). The Canadian Entomologist, 103, 1323-1335.

Chan, K.L. \& Saunders, L.G. (1965) Forcipomyia (Dacnoforcipomyia) anabaenae, a new blood-sucking midge from Singapore, described in all stages (Diptera: Ceratopogonidae). Canadian Journal of Zoology, 43, 527-540. https://doi.org/10.1139/z65-052

Edwards, F.W. (1922) On some Malayan and other species of Culicoides, with a note on the genus Lasiohelea. Bulletin of Entomological Research, 13, 161-167. https://doi.org/10.1017/S0007485300028030

Enderlein, G. (1936) Abt. 16. Ordnung: Zweiflügler, Diptera. In: Brohmer, P., Ehrmann, P. \& Ulmer, G. (Eds.), Die Tierwelt Mitteleuropas 6: Insekten III Teil. Verlag von Quelle \& Meyer, Leipzig, 259 pp.

Felippe-Bauer, M.L. \& Oliveira, S.J. de (2001) Lista dos exemplares tipos de Ceratopogonidae (Diptera, Nematocera) depositados na Coleção entomológica do Instituto Oswaldo Cruz, Rio de Janeiro, Brasil. Memorias do Instituto Oswaldo Cruz, 96, 1109-1119. https://doi.org/10.1590/S0074-02762001000800014

Grogan, W.L. Jr., Hribar, L.J., Murphree, C.S. \& Cilek, J.E. (2010) New records of biting and predaceous midges from Florida, including species new to the fauna of the United States (Diptera: Ceratopogonidae). Insecta Mundi, 0147, 1-59.

Harant, H., Huttel, W. \& Huttel, N. (1951) Parapterobosca anthropophila nov. gen., n. sp. Cératopogonide de la Cote d'Ivoire 
vulnérant pour l'homme. Annales de Parasitologie Humaine et Comparée, 26, 468-472.

Huerta, H. \& Ibáñez-Bernal, S. (1996) Especie nueva de Forcipomyia (Lasiohelea) de Chiapas, México (Diptera: Ceratopogonidae). Anales del Instituto de Biología Universidad Nacional Autónoma de México, Serie Zoología, 67, 349-355.

Huerta, H. \& Ibáñez-Bernal, S. (1999) A new species of Dasyhelea Kieffer (Diptera: Ceratopogonidae) and new records of biting midges from the State of San Luis Potosi, Mexico. Proceedings of the Entomological Society of Washington, 101, 496-502.

Kieffer, J.J. (1921) Sur quelques Diptères piqueurs de la tribu des Ceratopogoninae. Archives de l'Institut Pasteur de l'Afrique du Nord, 1, 107-115.

Lane, J. (1945) Redescrição de Ceratopogonideos Neotrópicos (Diptera: Ceratopogonidae) Revista de Entomologia, 16, 357-373.

Lane, J. (1947) A biologia e taxonomia de algumas espécies dos grupos Forcipomyia e Culicoides (Diptera, Ceratopogonidae) (Heleidae). Arquivos da Faculdade de Higiene e Saúde Pública da Universidade de São Paulo, 1, 159-170.

Lutz, A. (1913) Contribuição para o estudo das Ceratopogoninas hematofagas do Brazil. Memorias do Instituto Oswaldo Cruz, $5,45-73$.

Macfie, J.W.S. (1939) A report on a collection of Brazilian Ceratopogonidae (Dipt.). Revista de Entomologia, 10, $137-219$.

Macfie, J.W.S. (1940) Ceratopogonidae (Diptera) from British Guiana and Trinidad. Part 1. Proceedings of the Royal Entomological Society of London (B), 9, 179-186.

Macfie, J.W.S. (1944) Ceratopogonidae collected in Trinidad from cacao flowers. Bulletin of Entomological Research, 35 , 297-300.

Macfie, J.W.S. (1953) Ceratopogonidae from Costa Rica. Beiträge zur Entomologie, 3, 95-105.

Malloch, J.R. (1915) The Chironomidae, or midges, of Illinois, with particular reference to the species occurring in the Illinois River. Bulletin of the Illinois State Laboratory of Natural History, 10, 275-543.

Marino, P.I., Díaz, F. \& Ronderos, M.M. (2013) A new species of Forcipomyia (Phytohelea) from Argentina (Diptera: Ceratopogonidae). Revista Mexicana de Biodiversidad, 84, 818-824. https://doi.org/10.7550/rmb.35015

Marino, P.I. \& Spinelli, G.R. (2001) El subgenera Forcipomyia (Euprojoannisia) en la Patagonia (Diptera, Ceratopogonidae). Gayana, 65, 11-18.

Marino, P.I. \& Spinelli, G.R. (2005) First descriptions of females of two Neotropical species of Forcipomyia (Diptera, Ceratopogonidae). Deutsche Entomologische Zeitschrift, 1, 165-168.

Marino, P.I. \& Spinelli, G.R. (2008) The Forcipomyia (Forcipomyia) argenteola group in southern South America, with a key to the Neotropical species (Diptera: Ceratopogonidae). Revista de Biología Tropical, 56, 789-794.

Meigen (1818) Systematische Beschreibung der bekannten europäischen zweiflügeligen Insekten. Vol. 1. Bei Friedrich Wilhelm Forstmann: Gedrukt bei Beaufort Sohn, Aachen, xxxvi + 333 pp., 11 pls.

Ortiz, I. (1952) Nota sobre la presencia en Venezuela de un nuevo ceratopogónido hematófago: Lasiohelea stylifer (Lutz, 1913). Revista de Sanidad y Asistencia Social, 17, 241-246.

Ronderos, M.M. \& Spinelli, G.R. (1999) On the subgenus Forcipomyia (Lasiohelea) in the Neotropical Region (Diptera: Ceratopogonidae). Transactions of the American Entomological Society, 125, 151-161.

Saunders, L.G. (1957) Revision of the genus Forcipomyia based on characters of all stages (Diptera, Ceratopogonidae). Canadian Journal of Zoology, 34, 657-705. [1956]

Saunders, L.G. (1959) Methods for studying Forcipomyia midges, with special reference to cacao-pollinating species (Diptera, Ceratopogonidae). Canadian Journal of Zoology, 37, 33-51. https://doi.org/10.1139/z59-005

Saunders, L.G. (1964) New species of Forcipomyia in the Lasiohelea complex described in all stages (Diptera, Ceratopogonidae). Canadian Journal of Zoology, 42, 463-482. https://doi.org/10.1139/z64-040

Spinelli, G.R., Marino, P.I. \& Borkent, A. (2012) A revision of biting midges of the subgenera Forcipomyia (Metaforcipomyia) and F. (Saliohelea) from Costa Rica (Diptera: Ceratopogonidae). Zootaxa, 3419, 1-52.

Spinelli, G.R., Ronderos, M.M., Díaz, F. \& Marino, P.I. (2005) The bloodsucking biting midges of Argentina (Diptera: Ceratopogonidae). Memorias do Instituto Oswaldo Cruz, 100, 137-150. https://doi.org/10.1590/S0074-02762005000200006

Spinelli, G.R., Schaefer, E.F. \& Kehr, A.I. (2002) First record of biting midges (Diptera: Ceratopogonidae) attacking frogs in the Neotropical region. Proceedings of the Entomological Society of Washington, 104, 527-528.

Westwood, J.O. (1840) Order XIII. Diptera Aristotle (Antliata Fabricius. Halteriptera Clairv.). In: An introduction to the modern classification of insects; founded on the natural habits and corresponding organization of the different families. Synopsis of the genera of British insects. Longman, Orme, Brown, Green \& Longmans, London, pp. 125-154.

Wilkening, A.J., Kline, D.L. \& Wirth, W.W. (1985) An annotated checklist of the Ceratopogonidae (Diptera) of Florida with a new synonymy. Florida Entomologist, 68, 511-537. https://doi.org/10.2307/3494854

Wirth, W.W. (1956) The heleid midges involved in the pollination of rubber trees in America (Diptera, Heleidae). Proceedings of the Entomological Society of Washington, 58, 241-250.

Wirth, W.W. (1974) Family Ceratopogonidae. In: A catalogue of the Diptera of the Americas south of the United States, Fasc.14, pp. 1-89. 